\title{
Cultural values and start-up rates in the Spanish provinces
}

\author{
José Fernández
}

University of Seville, jfserrano@us.es

\section{Francisco Liñán}

University of Sevilla, flinan@us.es

\section{Isidoro Romero}

University of Sevilla, isidoro@us.es

\section{Acknowledgements}

This study it is part of the VIE Project (Cultural Values and Socioeconomic Factors as determinants of the Entrepreneurial Intention), which has been financed by the regional government of Andalusia (Department of Innovation, Science and Enterprise; Reference Number: P08-SEJ-03542).

We are also grateful to the universities collaborating in the data gathering (a complete list of them is published at the project web-page: http://institucional.us.es/vie). 


\title{
Cultural values and start-up rates in the Spanish provinces
}

\begin{abstract}
Countries with similar economic situations exhibit persistently different entrepreneurial activity levels. Cultural values have been called for to explain this difference. They may condition individuals' behaviour and significantly affect the society's entrepreneurship rates. Nevertheless, few empirical studies have focused on this relationship at the regional or local level. This paper tries to fill this gap in the literature by analysing how specific cultural values (as defined by Schwartz, 1999) can influence the number of start-ups in the different Spanish provinces. Findings indicate the effect to be significant, contributing to explain up to $65.6 \%$ of the variance in start-up rates.
\end{abstract}

Keywords: Entrepreneurship; intention; questionnaire; attitudes; self-efficacy

\section{INTRODUCTION}

It is widely accepted today that entrepreneurs are a driving force for innovation, job creation and economic growth. Accordingly, these agents have received increasing attention by policy-makers and also by the academic community. Different studies have shown that entrepreneurship can contribute significantly to economic growth, job creation and innovation (Reynolds et al., 2005; Carree et al. 2007). There is, therefore, high interest in understanding what factors are determining the level of entrepreneurship of the different countries or regions.

In this sense, the attempts to explain the level of entrepreneurial activity in each area have not been completely successful. Previous research in this respect have tended to find a U-shaped relationship between the level of economic activity and that of entrepreneurship (Carree, van Stel, Thurik \& Wennekers, 2002; Sternberg \& Wennekers, 2005; Wennekers, van Stel, Thurik \& Reynolds, 2005). After a certain level of per capita GDP, which has been set by some authors around US\$ 7000 (Pinillos \& Reyes, 2011), increased income leads to higher start-up rates. The reason may be that wealthier countries have a more complex economic system and also a greater demand for new and differentiated consumer goods, both leading to increased opportunities (Shane, 1993).

However, countries with similar development levels present persistent differences in their levels of entrepreneurship (Pinillos \& Reyes, 2011; van Stel, Carree \& Thurik, 2005). There is evidence that culture may be one very relevant component explaining these differences (Davidsson, 1995; Davidsson \& Wiklund, 1997; Hayton, George \& Zahra, 2002; Shane, 1993; Wennekers, Thurik, van Stel \& Noorderhaven, 2007). In this sense, the OECD (1998), recognizes that entrepreneurship is the result of three dimensions working together: conducive framework conditions, well-designed government programmes and supportive cultural attitudes.

Therefore, the influence of cultural values on entrepreneurship should deserve more 
attention. Up until now, research on culture and entrepreneurship has been limited. It has mostly focused on the individualism-collectivism continuum as explaining entrepreneurial activity (Morris, Davis \& Allen, 1994; Pinillos \& Reyes, 2011; Tiessen, 1997). Results from these studies have normally led to the conclusion that individualistic values favour entrepreneurial activity (Thomas \& Mueller, 2000). But culture is a multidimensional phenomenon (Hofstede, 2003; Schwartz, 1999). Therefore, this value-dimension alone may not reflect the complete influence of culture on entrepreneurship. Other authors have considered alternative cultural variables, such as uncertainty avoidance (Wennekers, et al., 2007). Attempts at analysing several of these dimensions together are still rare. One exception is Mueller and Thomas (2001), who jointly analysed the role of individualism and uncertainty avoidance, or Shane (1993), who analysed the effect of four cultural variables on innovation.

In any case, the vast majority of this research has been based on Hofstede's (2003) classification of cultural values. However, these data were collected more than forty years ago, which may cause doubts regarding its present-day validity (Tang \& Koveos, 2008). At the same time, alternative classifications have emerged. In particular, Schwartz (1992) defines the personal value structure as composed of ten basic values, which can be grouped into four value dimensions. Shared individual values form the basis of the cultural values of a society (Schwartz, Melech, Lehmann, Burgess \& Harris, 2001).

Overall, there is a clear lack of comprehensive research on the effect of cultural values on entrepreneurship using up-to-date multidimensional measures. This paper aims to fill this gap in the literature by assessing the specific effect of several cultural value-dimensions on start-up rates. To do so, the 52 Spanish provinces will be used. Differently from other countries, such as Sweden (Davidsson \& Wiklund, 1997), Spain is a culturally diverse country, with four official languages and very varied regional traditions. Besides, although all of them may be considered high-income areas, substantial differences are also found with respect to income level and entrepreneurial activity (start-up rates).

After this introduction, next section outlines the relevant theory and the hypotheses derived from it. Section 3 describes the empirical analysis. Results are presented in section 4 and discussed in section 5 . The paper ends with a conclusion section.

\section{THEORY AND HYPOTHESES}

The relationship between economic development and entrepreneurship will be briefly considered. After that, the role of culture and its operationalization is studied. Finally, the research hypotheses are presented.

\subsection{Economic development and entrepreneurship}

Entrepreneurship plays a very important role in the process of national and regional economic development. It increases employment opportunities, enhances technical innovation level, and promotes economic development (Audretsch \& Fritsch, 1999; Fritsch \& 
Mueller, 2004; Reynolds, Bygrave, Autio \& Hay, 2002; van Stel \& Storey, 2004). From a dynamic perspective, entrepreneurs are agents of change and entrepreneurship implies starting new businesses, experimenting with new techniques and a new organization of production, introducing new products or even creating new markets (Wennekers, Uhlaner \& Thurik, 2002).

Minniti, Bygrave and Autio (2006) and Lee and Peterson (2000) found the income level to have an effect on the level of entrepreneurial activity. In particular, the rate of growth in income has been found to have an influence on start-up rates (Armington \& Acs, 2002; Lee, Florida \& Acs, 2004). Similarly, when income is measured as per capita GDP, the effect on entrepreneurship is positive as well (Fishman \& Sarria-Allende, 2004; Parker \& Robson, 2004). However, development might be accompanied by raising real wages, in turn raising the opportunity costs for self-employment, and so GDP per capita could reduce entrepreneurial activity (Bjornskov \& Foss, 2006; Noorderhaven, Thurik, Wennekers \& van Stel, 2004). In this sense, some authors (Van Stel, Wennekers, Thurik \& Reynolds, 2003; Verheul, Wennekers, Audretsch \& Thurik, 2002) have found a significant positive effect of the square of per capita GDP, suggesting a U-shaped impact of this income variable on entrepreneurship. Thus, for higher levels of income, a positive relationship between per capita GDP and entrepreneurship should be expected.

The level of economic development induces new firm formation since environmental opportunities and expected rewards of starting a business are higher (Carree, et al., 2002; Reynolds, Storey \& Westhead, 1994). Individuals may be pulled toward a decision to start a business based on perceived environmental opportunities. Therefore, per capita GDP is a factor that influences demand in a specific region, as higher levels of income increase demand and opportunities for the entrepreneurs. Further, there is evidence that the average level of income and wealth determines the variety of consumer demand. A high differentiation in demand favours the suppliers of new and specialized products and diminishes the scale advantages of large incumbent firms (Jovanovic, 1993; Wennekers, et al., 2002).

In modern economies, economic growth is profoundly associated with capital accumulation. Investment in new assets and capital goods is needed to produce new goods and services (Attanasio, Picci \& Scorcu, 2000; Barro \& Sala-i-Martin, 1995). Of course, this may also depend on the sectoral composition of production. Regions based on manufacturing will exhibit higher capital accumulation than regions based on less capital-intensive sectors, such as agriculture or tourism. Overall, however, the capital stock has been found to positively affect entrepreneurship rates (Acs, Audretsch \& Evans, 1994; Audretsch, Thurik, Verheul \& Wennekers, 2002).

Additionally, market demand, is another factor influencing regional entrepreneurial activity (Armington \& Acs, 2002; Sutaria \& Hicks, 2004). Entrepreneurs are willing to start new businesses in bigger market-demand regions. In this sense, the rate of growth of the population has positive effects on entrepreneurship levels (Armington \& Acs, 2002; Lee, et al., 2004; Sutaria \& Hicks, 2004). Similarly, Fritsch and Mueller (2004) and Bartik (1989) reported that population density produced strongly positive effect on regional entrepreneurial activity. In regions with higher population density, more potential consumers can be provided for by new businesses. 


\subsection{Culture and entrepreneurship}

Inglehart (1997) defines culture as the set of basic common values which contributes to shaping people's behaviour in a society. Cultural values operate unconsciously, since they are deeply rooted within the political institutions and technical systems. Therefore, these values and beliefs are continuously reinforced (Pinillos \& Reyes, 2011). Culture shapes the individual's cognitive schemes, programming behavioural patterns which are consistent with the cultural context (Hofstede, 1991, 2003).

Culture may influence entrepreneurship through two main mechanisms (Davidsson, 1995). Firstly, a supportive culture would lead to social legitimation, making the entrepreneurial career more valued and socially recognized in that culture, thus creating a favourable institutional environment. Therefore, more people will try to start their ventures, irrespective of their personal beliefs and attitudes (Etzioni, 1987). Secondly, a culture sharing more pro-entrepreneurial values and patterns of thinking would lead to more individuals showing psychological traits and attitudes consistent with entrepreneurship (Krueger, 2000, 2003; Santos, Liñán \& Fernández, 2009). Thus, more people will try to become entrepreneurs (Mcgrath, MacMillan, Yang \& Tsai, 1992; Mueller \& Thomas, 2001). In this sense, it has been suggested that a high perceived valuation of entrepreneurship in a society will lead to more positive attitudes and intentions by individuals (Krueger \& Carsrud, 1993; Liñán, Urbano \& Guerrero, 2011). Alternatively, it has also been argued that it is "misfit" individuals who attempt to start a venture. That is, irrespective of the specific cultural characteristics of a country, people not sharing dominant cultural values -dissatisfied individuals- will attempt the entrepreneurial path (Hofstede, et al., 2004).

The first and most common classification of cultures distinguishes between individualist and collectivistic ones (Hofstede 1980; Triandis 1995; Schwartz 1999). However, alternative characterizations have also been made. Thus, Inglehart (1997) considers modernization -with emphasis in economic and physical security- and post-modernization -priority of selfexpression and intellectual and aesthetic satisfaction- as one of the essential differentiating elements.

From an empirical point of view, Hofstede's cultural dimensions of individualism, uncertainty avoidance, power-distance and masculinity (Hofstede, 1980, 1991, 2003) have been used as a reference in most research about the influence of culture on entrepreneurship (Hayton, et al., 2002; Liñán \& Chen, 2009; Mcgrath \& MacMillan, 1992; Mitchell, Smith, Seawright \& Morse, 2000; Mueller \& Thomas, 2001; Mueller, Thomas \& Jaeger, 2002; Shane, Kolvereid \& Westhead, 1991). Results have confirmed their influence on national start-up rates, innovation or entrepreneurial intentions. However, Hofstede's measures are more than 40 years old, and they are only available at the national level (Tang \& Koveos, 2008). Therefore, its use to analyse present-day intra-country differences may be questioned.

Even though most of this research has tended to identify culture with nation, a number of changes (increasing development of technology and information systems, globalization of markets and migratory flows) have modified this traditional identification (García-Cabrera \& García-Soto, 2008). The existence of intra-national cultural differences should be acknowledged (Sackmann \& Phillips, 2004). For this reason, regional variations in cultural values may contribute to explaining differences in entrepreneurship levels within a country (Davidsson, 1995; Davidsson \& Wiklund, 1997). 
In the present research, the aggregate effect of culture on entrepreneurship should be explored (Hofstede, et al., 2004). That is, it is assumed that an area where the majority of its inhabitants share some specific value priorities would develop more favourable institutions and general environment, making more people start their ventures (Davidsson, 1995). It may also be that, at the same time, more individuals show psychological traits and attitudes consistent with entrepreneurship (Krueger, 2000, 2003), but this will not be specifically tested here.

According to Schwartz (1990), values shape the individual's motivational goals. A circular structure of values is proposed (see Figure 1) representing the dynamic relationships between values according to principles of compatibility and logical contradiction. Following this circular structure, the pursuit of adjacent values (e.g., power and achievement, or stimulation and self-direction) is compatible, whilst the pursuit of opposing values (e.g., power and universalism) would generate conflict (Schwartz, 1999; Schwartz, et al., 2001).

\section{Figure 1. The circular structure of values}

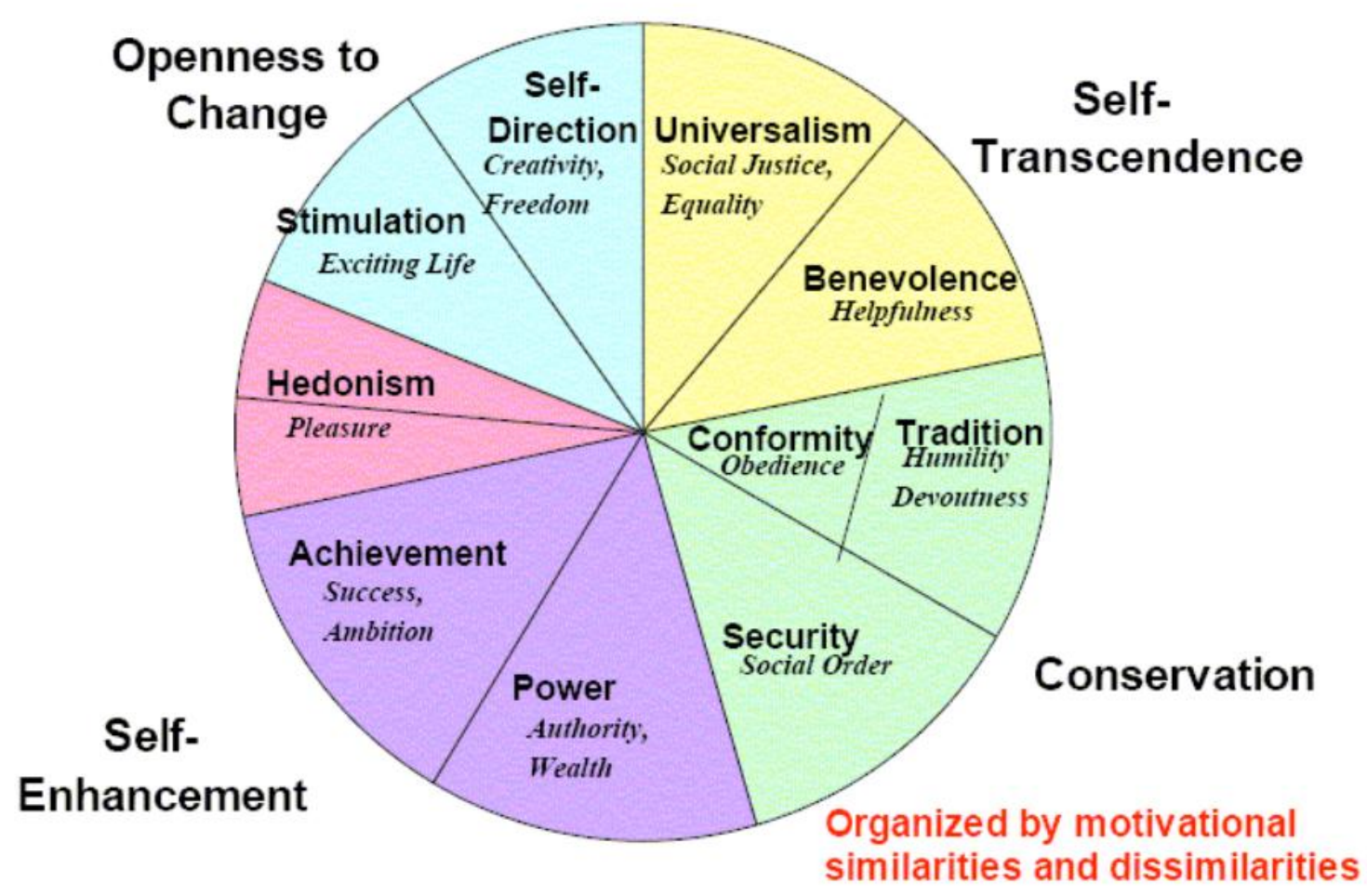

Source: Schwartz (2006)

The ten types of values proposed by Schwartz (2006) would be grouped into four main value dimensions: Openness to change (referring to aspects such as stimulation, self-direction or hedonism); Self-enhancement (stressing values such as achievement and power); Conservation (conformity, tradition and security values) and Self-transcendence (with valuepriorities such as benevolence and universalism). The first two of these dimensions may be associated with individualism, whereas the other two are partly related to collectivism. At the personal level, openness to change and self-enhancement has been found to be positively associated to the entrepreneurial intention (Jaén, Moriano \& Liñán, Forthcoming). 


\subsection{Research hypotheses}

Based on the review of the relevant theory, the existence of a relationship between economic variables and entrepreneurship is assumed. In this sense, these variables will be used as initial control variables in the empirical analysis. The achieve the purpose of this research, a number of hypotheses about the role of culture will be formulated. Even though there is a paucity of research using these four value dimensions to explain entrepreneurship, Schwartz (1999) associates Openness to change and Self-enhancement with individualism, whereas the other two dimensions would be related to collectivism. Jaén, Moriano and Liñán (Forthcoming) linked the first two values with a higher entrepreneurial intention. Based on this, the hypotheses to be tested will be:

H1: Provinces where Openness to change is prioritized by their citizens will exhibit higher start-up rates.

H2: Provinces where Self-enhancement is prioritized by their citizens will exhibit higher start-up rates.

H3: Provinces where Conservation is prioritized by their citizens will exhibit lower start-up rates.

H4: Provinces where Self-Transcendence is prioritized by their citizens will exhibit lower start-up rates.

\section{EMPIRICAL ANALYSIS: DATA AND METHODOLOGY.}

\subsection{Data and measures}

Data used for this study combine official statistics with questionnaire-based information. Economic and demographic information has been obtained from well-known research and statistics bodies. However, information on cultural differences between the Spanish provinces tends to be anecdotal, and the authors are not aware of any previous study providing these data. Therefore, cultural values has been collected as part of the development of the VIE project, as described below.

Hierarchical linear regression analysis has been used to test the hypotheses. The customary precautions with respect to the presence of heteroscedasticity or multicollinearity have been considered.

\subsection{Measures.}

Regarding entrepreneurship, there is neither a universal definition of this concept nor a universal set of indicators. Therefore, measurement and comparison of the level of entrepreneurship for different time periods and countries is difficult (Lichtenstein, Dooley \& Lumpkin, 2006; Lumpkin \& Dess, 1996; OECD, 1998). To capture the dynamic aspect of entrepreneurship, it is often measured as nascent and start-up entrepreneurial activity, gross or net entry of new firms, or even the turbulence rate (total of entry and exit). In the present 
study, entrepreneurial activity will be measured as follow:

- Net firm entry for 2000-2008 (average). This rate is available at the province level from the DIRCE dataset ${ }^{1}$. The reasons for choosing this period are twofold. First, it's a homogeneous period of economic growth. Thus, we avoid the possible distortions effects of the economic crisis. Second, an average of several years would minimize the risk of measurement errors and anomalous observations.

According Wennekers et al. (2001; 2002), the main sources of variation in entrepreneurship across countries and regions can be traced to differences in the level of economic development, demography and to cultural and institutional differences. Therefore, these three groups of variables will be considered in our analysis.

Regarding economic variables, Gross domestic product (GDP) per capita and Capital stock are often used as measures of income, standards of living or wealth and, therefore, the level of development of a territory. Thus, the following economic variables are used:

- GDP per capita (average 2000-2008). Calculated with data from the Spanish Regional Accounts available at the National Statistics Institute, (Instituto Nacional de Estadística, INE).

- Net Capital Stock (average 2000-2008). Calculated with data from the BBVA foundation.

Additionally, two demographic indicators have been included to reflect the local market size and the expectations of market growth (Bartik, 1989; Fritsch \& Mueller, 2004; Wennekers, et al., 2001). Data are obtained from the INE:

- Population density (average 2000-2008) is the population in the province divided by regional area.

- Rate of population growth (average 2000-2008) reflects the yearly average change in population during the period in each province.

In this paper, the hypotheses about cultural variables will be tested using the VIE project dataset. Raw data were obtained through a web based questionnaire. Data collection stretched from February to October 2010. A total of 4029 responses were available. An initial depuration test removed responses from students and immigrants, since the purpose of this research is analysing cultural values and they are defined as those values shared by the local population. Therefore, the final usable sample for this study was 3061 from 52 Spanish provinces.

Schwartz's (2007) Portarit Value Questionnaire (PVQ) has been used to measure values. The PVQ includes short verbal portraits of 40 people. Each portrait describes a person's goals, aspirations or wishes that point implicitly to the importance of one of the 10 value types on the individual level. Respondents are asked to answer "How much like you is this person?" on a seven-point scale, ranging from 0 (not at all like me) to 6 (very similar to me). Firstly, since the interest yields in value priorities, the individual's average response to the 40 items has been subtracted from each of his/her responses to the items. In this form, deviations from the mean are obtained. Positive scores indicate the item to be a value priority, whereas negative scores reflect a value not relevant for the individual. Secondly, the value priorities of

\footnotetext{
${ }^{1}$ www.ine.es (Economy/Central Companies Directory: statistical use).
} 
all individuals in each province have been averaged to reflect the cultural value priorities in that province. The provincial value priorities have then been used to estimate scores for each of the ten value types described in Figure 1.

Three provinces had to be eliminated from the analysis (Ceuta, Melilla and Huesca), since a single observation was available. Therefore, the cultural dataset is composed of 10 value types for 49 Spanish provinces. There is a minimum of four observations for Rioja and a maximum of 520 observations for Seville. There are 25 provinces with more than 20 observations each. Based on this information, the four cultural value dimensions have been computed for each province:

- Openness to change (average of stimulation, hedonism and self-direction values).

- Conservation (average of tradition, conformity and security values).

- Self-enhancement (average of achievement and power values).

- Self-transcendent (average of universalism and benevolence values).

\section{RESULTS}

\subsection{Linear regression analysis.}

Once the measures have been established, a linear regression analysis was performed to test the hypotheses formulated in the theory section. Three linear regression models have been estimated with entrepreneurship growth as the dependent variable in all occasions. Table 1 presents a correlation matrix between the explained and the explanatory variables. As may be seen, population growth, openness to change and self-enhancement are significantly and positively correlated to the dependent variable.

Table 1. Pearson's correlations

\begin{tabular}{|c|c|c|c|c|c|c|c|c|c|c|}
\hline & & 1 & 2 & 3 & 4 & 5 & 6 & 7 & 8 & 9 \\
\hline 1 & Net Firm entry & 1 & & & & & & & & \\
\hline 2 & Density & .103 & 1 & & & & & & & \\
\hline 3 & Population Growth & $.597^{* * *}$ & .212 & 1 & & & & & & \\
\hline 4 & GDP per capita & -.114 & $.434^{* *}$ & $.294^{*}$ & 1 & & & & & \\
\hline 5 & Capital Stock & .187 & $.841^{* * *}$ & .246 & $.368^{* *}$ & 1 & & & & \\
\hline 6 & Openness to change & $.318^{*}$ & .020 & .204 & -.101 & .147 & 1 & & & \\
\hline 7 & Self-transcendence & -.276 & .191 & -.172 & -.067 & .109 & .176 & 1 & & \\
\hline 8 & Conservation & -.098 & .010 & -.249 & -.204 & -.051 & $-.702^{* * * *}$ & -.201 & 1 & \\
\hline 9 & Self-enhancement & $.392^{* *}$ & -.161 & $.306^{*}$ & .077 & -.057 & -.028 & $-.794^{* * * *}$ & -.172 & 1 \\
\hline
\end{tabular}

Model 1, in Table 2, corresponds to economic and demographic variables. The tests for heteroscedasticity show that this is not a problem here. However, multicollinearity was 
present, with condition index scoring up to 19.083. To solve this problem, following practice (Pinillos \& Reyes, 2011; Venkatraman, 1989), two variables were centred (change of origin, with zero mean): net capital stock and GDP per capita. In this way, the highest Variance Inflation Factor (VIF) is reduced to 4.8 and the highest condition index is 8.258 , indicating multicollinearity is no longer a problem. In Table 2, results from this first regression model are displayed. The explanatory capacity of this model is high $\left(\mathrm{R}^{2}=.533\right)$, and only one nonsignificant variable emerges (density). The most influential variable is population growth $\left(\beta=.576^{* * *}\right)$. The signs are expected, except for GDP per capita. For this latter variable, a quadratic effect (with positive coefficient for the squared income) might be present.

In the second model, we have only tested cultural-variable effects. As in model 1, heteroscedasticity and multi-collinearity were checked for. As was expected, multicollinearity was present (the condition index achieves a value of 28). Therefore, these variables are centred, as before, to solve this problem. A weighted backward-stepwise linear regression model is then run, with the weights being the number of observations in each province. Multicollinearity is corrected (condition index below 3 and VIF below 2). Results tend to support hypotheses $\mathrm{H} 1$ and $\mathrm{H} 3$ (positive significant coefficient for Openness to change and Self-enhancement). In contrast, the signs of the coefficients for the other two cultural variables are against expectations. In particular, Self-transcendence is nonsignificant. This model 2 explains $41.2 \%$ of the variance in the dependent variable.

Table 2: Linear regression models on entrepreneurship and cultural relationship.

\begin{tabular}{|c|c|c|c|}
\hline Variables & $\begin{array}{c}\text { Model } 1 \\
\qquad B\end{array}$ & $\begin{array}{c}\text { Model } 2 \\
\beta\end{array}$ & $\begin{array}{c}\text { Model } 3 \\
\qquad \beta\end{array}$ \\
\hline \multicolumn{4}{|l|}{ Control variables. } \\
\hline Density & .053 & & .322 \\
\hline Population Growth & $.576 * * *$ & & $.556^{* * * *}$ \\
\hline GDP per capita (centred) & $-.484 * *$ & & -.231 \\
\hline Capital Stock (centred) & $.398 \ddagger$ & & -.152 \\
\hline \multicolumn{4}{|l|}{ Cultural variables. } \\
\hline Openness to change (centred) & & $.769 * * *$ & $.634 * * *$ \\
\hline Conservation (centred) & & $.506^{* *}$ & $.500 * *$ \\
\hline Self-enhancement (centred) & & $.689^{* *}$ & $.385 \ddagger$ \\
\hline Self-transcendence (centred) & & .354 & .150 \\
\hline$\overline{\mathrm{R}^{2}}$ & .572 & .461 & .711 \\
\hline Adjusted $\mathrm{R}^{2}$ & .533 & .412 & .653 \\
\hline F-statistic & $14.687 * * *$ & $9.391 * * *$ & $12.296 * * *$ \\
\hline
\end{tabular}

Dependent variable: Net entry of firms for 2000-2008.

Note: $\ddagger p<0.1, * p<.05, * * p<.01 ., * * * \mathrm{p}<.001$

Finally, model 3 includes the four control variables and the four cultural variables together, using a weighted linear regression. The fit of this model is good, since it explains $65.3 \%$ of the variance on entrepreneurship. The signs and levels of the coefficients are 
similar to those in models 1 and 2 for most variables. The number of significant variables is lower, though. The coefficient for population density is higher, but still not significant. In contrast, GDP per capita and capital stock become negative and non-significant. This is an interesting change that deserves some comments (see discussion below).

Overall, hypotheses $\mathrm{H} 1$ and $\mathrm{H} 2$ are supported (both openness to change and selfenhancement have significant and positive coefficients), whereas $\mathrm{H} 3$ and $\mathrm{H} 4$ are not. In the case of conservation, it is significant, but with a positive coefficient. Self-transcendence, in turn, is not significant and with the wrong coefficient.

\section{DISCUSSION}

As was expected, economic and demographic variables do explain a substantial fraction of the variance in start-up rates between the Spanish provinces. This is no surprise, since a number of studies have already established this relationship before. However, what is most interesting is that more than $40 \%$ of the difference in start-up rates is explained by cultural variables alone, and more than $65 \%$ when all variables are included. In Spain, contrary to other more homogeneous countries (Davidsson \& Wiklund, 1997), internal cultural variations are quite important, and this difference is reflected in start-up rates.

Nevertheless, economic relationships in this case should deserve some attention. The strongest predictor of start-ups within this group is population growth. That is, where the market is increasing, more opportunities are available and are then taken advantage of by new firms. Similarly, Capital stock in model 1 is positively related to start-ups. More developed provinces, relatively specialized in more capital-intensive sectors, present a higher start-up rate.

In contrast, when a direct measure of income is considered (GDP per capita) the relationship is negative and significant. Spain is a high-income country, with GDP per capita of around US\$ 30 000, well above the threshold suggested by some authors upon which there should be a positive relationship between income and entrepreneurship (Pinillos \& Reyes, 2011). One possible explanation for this finding would be that the U-shaped relationship (Van Stel, et al., 2003; Verheul, et al., 2002) is repeated here at a higher level. That is, within an economy, with a common market and institutional framework, the threshold mentioned would be much higher and a new U-shape relationship would be found, distinguishing between less-developed and more-developed areas of the country.

Alternatively, it may be the case that some interaction is present between population growth (or capital stock) and GDP per capita. Regions with higher income and living standards will probably attract immigrants from elsewhere. Therefore, part of the effect of income would be reflected in the coefficient for population growth. In this sense, a significant correlation between population growth and GDP per capita is found (.294* in Table 1). The same may be said with regard to capital stock, which is also positively and significantly correlated to GDP per capita $\left(.368^{* *}\right)$. Regions where capital stock is higher are normally those with higher income. Therefore, once the effect of population and capital stock is taken into account, the differential effect of GDP per capita would be negative. 
Those interaction effects would also be present between economic and cultural variables. As may be seen in model 3, when culture is included in the analysis, the coefficient for population growth remains nearly the same. In contrast, the coefficients for GDP per capita and Capital stock are substantially modified (even changing the sign) and become nonsignificant. Comparing to model 2 , it seems that this interaction is especially related to the values of Self-enhancement and Openness to change (the variation in their coefficients is greater). That is, people in more intensively capitalized provinces would tend to prioritize values such as self-enhancement and openness to change, to a greater extent than those in less capitalized areas.

In this sense, it is probably true that some cultural transformation occurs as the level of development increases and the product specialization is changed. This joint variation is reflected here in the form of interactions between economic and cultural variables. This is not to say, of course, that there is a direct linear relationship between income (or capital stock) and cultural values. If this were so, there would be no need to consider culture in the analysis. In contrast, these two groups of variables probably evolve independently, but each of them is one of the factors (among many others) explaining the change in the other.

Considering now the cultural variables, it may be seen in Table 1 that the signs and (for openness to change and self-enhancement) significance levels of the correlations are clearly in line with the hypotheses. Besides, the correlation between openness to change and conservation is negative and very strong $(-.702 * * *)$, as it is the one between selfenhancement and self-transcendence (-.794***), as predicted by Schwartz (1992; 2007). This is interesting, because it serves to confirm, at the cultural level, what was originally predicted for individual values.

When the regression analysis is carried out (Table 2, models 2 and 3), in turn, only H1 and $\mathrm{H} 2$ are confirmed, but not the others. In particular, conservation has a positive and significant effect on start-up rates. This result may be difficult to explain. A first interpretation, though, would be related to the different forms in which culture may affect entrepreneurship. According to Davidsson (1995), this effect could be exerted either through social legitimation or by promoting pro-entrepreneurial psychological traits. Additionally, it may also be that dissatisfied individuals are those who start their ventures (Hofstede, et al., 2004). Additionally, some researchers point out that the effect of culture on entrepreneurship may be different depending on the development level (Pinillos \& Reyes, 2011; Wennekers, et al., 2007).

The present study does not allow to reach a conclusion on which of these theories applies. But it may be the case that social legitimation, or even psychological traits, may be at play in more developed regions, where openness to change and self-enhancement would be prioritized. In turn, in less developed areas where conservation and self-transcendence would prevail, dissatisfied individuals may be the ones that start their ventures. Alternatively, it may also be the case that less-developed provinces in Spain would prioritize conservation and self-enhancement values, and this would be promoting the starting of new ventures (as a social legitimation or psychological traits effects) by integrated individuals. In turn, for more developed regions, other cultural values (openness to change and self-enhancement) are the ones to promote entrepreneurship. This second argument would be similar to others posed at the country level (Pinillos \& Reyes, 2011; Wennekers, et al., 2007). 


\section{CONCLUSION}

The main objective of this research, we believe, has been achieved. The effect of cultural values on entrepreneurship has been studied on a set of provinces with a common institutional framework, and up-to-date measures. Besides, this paper has gone further than the usual individualism-collectivism dichotomy. Results confirm that cultural values play a relevant role in explaining start-up rates either alone or together with economic and demographic variables. Values theoretically closer to entrepreneurship (openness to change and self-enhancement) have been found to be associated with higher venture creation at the province level. In turn, conservation values have also been associated with higher start-ups, against expectations.

There is probably still much to be known about the influence of culture on entrepreneurship. In this sense, one obvious avenue for future research resides in clarifying the way in which this influence is exerted. That is, whether it is social legitimation, psychological traits or dissatisfied individuals. As mentioned above, it may also be the case that a combination of the three modes of influence is at play. What is more, economic, demographic and some additional variables may alter the mode of influence, which would be different in each situation. In any case, to shed additional light on this issue, the combination of cultural values with personal-level attitudes is needed. And this is, precisely, what the ongoing VIE research project offers. Therefore, it is a line of research that the authors plan to pursue in the near future.

The present research may suffer from a number of limitations. Firstly, cultural values have been measured as the average of the relative priorities of individuals in each province. Although, as far as we know, this is completely justified, alternative measures may lead to varying results. Secondly, sample size at the individual level was large, but when grouped into provinces, the number of observations for some of them was low. To try to minimize this limitation, a weighted least squared procedure was used. Thirdly, cultural values have been measured in 2010, whereas economic and demographic data correspond to the period 20002008. This may be a problem, but only to the extent that province-level cultural-value priorities have changed appreciably between 2000 and 2010. Several authors have claimed that culture is stable over time and changes very slowly (Hayton, et al., 2002; Hofstede, 1980, 1991, 2003; Mcgrath \& MacMillan, 1992; Mitchell, et al., 2000; Mueller \& Thomas, 2001; Mueller, et al., 2002; Shane, et al., 1991). Nevertheless, the study may be repeated in the future when economic and demographic data after 2010 are available.

\section{REFERENCES}

Acs, Z. J., Audretsch, D. B., \& Evans, D. S. (1994). The determinants of variations in selfemployment rates across countries and over time. Discussion Paper 871. London: Centre for Economic Policy Research.

Armington, C., \& Acs, Z. J. (2002). The Determinants of Regional Variation in New Firm Formation Regional Studies, 36(1), 33-45.

Attanasio, O., Picci, L., \& Scorcu, A. E. (2000). Saving, growth, and investment: a macroeconomic analysis using a panel of countries. The Review of Economics and Statistics, 82(2), 182-211.

Audretsch, D. B., \& Fritsch, M. (1999). The Industry Component of Regional New Firm Formation Processes. Review of Industrial Organization, 15(3), 239-252. 
Audretsch, D. B., Thurik, A. R., Verheul, I., \& Wennekers, A. R. M. (Eds.). (2002). Entrepreneurship: Determinants and Policy in a European-US Comparison. Boston/Dordrecht: Kluwer Academic Publishers.

Barro, R. J., \& Sala-i-Martin, X. (1995). Economic Growth. New York, NY: McGraw-Hill.

Bartik, T. J. (1989). Small Business Start-ups in the United States: Estimates of the Effects of Characteristics of States. Southern Economic Journal, 55(4), 1004-1018.

Bjornskov, C., \& Foss, N. J. (2006). Economic freedom and entrepreneurial activity: Some crosscountry evidence. DRUID Working paper, 06-18.

Carree, M. A., van Stel, A., Thurik, A. R., \& Wennekers, A. R. M. (2002). Economic development and business ownership: an analysis using data of 23 OECD countries in the period 19761996. Small Business Economics, 19(3), 271-290.

Davidsson, P. (1995). Culture, structure and regional levels of entrepreneurship. Entrepreneurship and Regional Development, 7(1), 41-62.

Davidsson, P., \& Wiklund, J. (1997). Values, beliefs and regional variations in new firm formation rates. Journal of Economic Psychology, 18(2-3), 179-199.

Etzioni, A. (1987). Entrepreneurship, adaptation and legitimation: a macro-behavioral perspective. Journal of Economic Behavior \& Organization, 8, 175-189.

Fishman, R., \& Sarria-Allende, V. (2004). Regulation of entry and the distortion of industrial organization. Working Paper No. 10929. Cambridge, MA: National Bureau of Economic Research.

Fritsch, M., \& Mueller, P. (2004). Effects of New Business Formation on Regional Development over Time. Regional Studies, 38(8), 961-975.

García-Cabrera, A. M., \& García-Soto, M. G. (2008). Cultural differences and entrepreneurial behaviour: an intra-country cross-cultural analysis in Cape Verde. Entrepreneurship and Regional Development, 20(5), 451-483

Hayton, J. C., George, G., \& Zahra, S. A. (2002). National culture and entrepreneurship: a review of behavioral research. Entrepreneurship Theory and Practice, 26(4), 33-52.

Hofstede, G. (1980). Culture's consequences: international differences in work-related values. Beverly Hills: Sage Publications.

Hofstede, G. (1991). Cultures and organizations: software of the mind. London: McGraw-Hill.

Hofstede, G. (2003). Culture's consequences: comparing values, behaviors, institutions and organizations across nations (2nd edition ed.). Newbury Park: Sage Publications.

Hofstede, G., Noorderhaven, N., Thurik, A. R., Uhlaner, L. M., Wennekers, A. R. M., \& Wildeman, R. E. (2004). Culture's role in entrepreneurship: self-employment out of dissatisfaction. In T. E. Brown \& J. M. Ulijn (Eds.), Innovation, entrepreneurship and culture (pp. 162-203). Cheltenham: Edward Elgar.

Inglehart, R. (1997). Modernization and Postmodernization. Princeton: Princeton University Press.

Jaén, I., Moriano, J. A., \& Liñán, F. (Forthcoming). Personal values and entrepreneurial intentions: an empirical study. In P. Kyrö \& A. Fayolle (Eds.), Entrepreneurship research in Europe. Cheltenham, UK: Edward Elgar.

Jovanovic, T. B. (1993). The Diversification of Production. Brookings Papers on Economic Activity, Microeconomics, 1993(1), 197-235.

Krueger, N. F. (2000). The cognitive infrastructure of opportunity emergence. Entrepreneurship Theory and Practice, 24(3), 5-23.

Krueger, N. F. (2003). The cognitive psychology of entrepreneurship. In Z. J. Acs \& D. B. Audretsch (Eds.), Handbook of entrepreneurship research: An interdisciplinary survey and introduction (pp. 105-140). London: Kluwer.

Krueger, N. F., \& Carsrud, A. L. (1993). Entrepreneurial intentions: applying the theory of planned behavior. Entrepreneurship and Regional Development, 5(4), 315-330.

Lee, S. M., \& Peterson, S. J. (2000). Culture, entrepreneurial orientation, and global competitiveness. Journal of World Business, 35(4), 401-416.

Lee, S. Y., Florida, R., \& Acs, Z. J. (2004). Creativity and entrepreneurship: A regional analysis of new firm formation. Regional Studies, 38(8), 879-891.

Lichtenstein, B. B., Dooley, K. J., \& Lumpkin, G. T. (2006). Measuring emergence in the dynamics of new venture creation. Journal of Business Venturing, 21(2), 153-175. 
Liñán, F., \& Chen, Y. W. (2009). Development and cross-cultural application of a specific instrument to measure entrepreneurial intentions. Entrepreneurship Theory and Practice, 33(3), 593-617.

Liñán, F., Urbano, D., \& Guerrero, M. (2011). Regional variations in entrepreneurial cognitions: Start-up intentions of university students in Spain. Entrepreneurship and Regional Development, 23(3\&4), 187-215. doi: 10.1080/0898562090323392

Lumpkin, G. T., \& Dess, G. G. (1996). Clarifying the entrepreneurial orientation construct and linking it to performance. Academy of Management Review, 21(1), 135-172.

Mcgrath, R. G., \& MacMillan, I. C. (1992). More Like Each Other Than Anyone Else - a CrossCultural Study of Entrepreneurial Perceptions. Journal of Business Venturing, 7(5), 419-429.

Mcgrath, R. G., MacMillan, I. C., Yang, E. A., \& Tsai, W. (1992). Does Culture Endure, or Is It Malleable - Issues for Entrepreneurial Economic-Development. Journal of Business Venturing, 7(6), 441-458.

Minniti, M., Bygrave, W. D., \& Autio, E. (2006). GEM, Global Entrepreneurship Monitor, 2005 Executive Report. : . London, U.K. \& Babson Park, MA: London Business School \& Babson College.

Mitchell, R. K., Smith, B., Seawright, K. W., \& Morse, E. A. (2000). Cross-cultural cognitions and the venture creation decision. Academy of Management Journal, 43(5), 974-993.

Morris, M. H., Davis, D. L., \& Allen, J. (1994). Fostering corporate entrepreneurship: cross-cultural comparisons of the importance of individualism versus collectivism. Journal of International Business Studies, 25(1), 65-89.

Mueller, S. L., \& Thomas, A. S. (2001). Culture and entrepreneurial potential: A nine country study of locus of control and innovativeness. Journal of Business Venturing, 16(1), 51-75.

Mueller, S. L., Thomas, A. S., \& Jaeger, A. M. (2002). National entrepreneurial potential: the role of culture, economic development and political history. In M. A. Hitt \& J. L. C. Cheng (Eds.), Managing Transnational Firms: Resources, Market Entry and Strategic Alliances (Vol. 14, pp. 221-257). Amsterdam: JAI Press.

Noorderhaven, N., Thurik, R., Wennekers, S., \& van Stel, A. (2004). The role of dissatisfaction and per capita income in explaining self-employment across 15 European countries. Entrepreneurship-Theory and Practice, 28(5), 447-466.

OECD. (1998). Fostering entrepreneurship. Paris: Organisation for Economic Co-operation and Development.

Parker, S. C., \& Robson, M. (2004). Explaining International Variations in Self-Employment: Evidence from a Panel of OECD Countries. Southern Economic Journal, 71(2), 287-301.

Pinillos, M.-J., \& Reyes, L. (2011). Relationship between individualist-collectivist culture and entrepreneurial activity: evidence from Global Entrepreneurship Monitor data. Small Business Economics, 37(1), 23-37. doi: 10.1007/s11187-009-9230-6

Reynolds, P. D., Bygrave, W., Autio, E., \& Hay, M. (2002). Global Entrepreneurship Monitor. 2002 summary report. Kansas City: Ewin Marion Kauffman Foundation.

Reynolds, P. D., Storey, D. J., \& Westhead, P. (1994). Cross-national comparison of the variation in new firm rates. Regional Studies, 28(4), 443-456.

Sackmann, S. A., \& Phillips, M. E. (2004). Contextual Influences on Culture Research: Shifting Assumptions for New Workplace Realities. International Journal of Cross Cultural Management, 4(3), 370-390. doi: 10.1177/1470595804047820

Santos, F. J., Liñán, F., \& Fernández, J. (2009). Cognitive Aspects of Potential Entrepreneurs in Southern and Nothern Europe: an Analysis Using Gem-Data. Revista de Economía Mundial, $23,151-178$.

Schwartz, S. H. (1990). Individualism-Collectivism. Critique and proposed refinements. Journal of cross-cultural psychology, 21(2), 139-157.

Schwartz, S. H. (1992). Universals in the content and structure of values: Theoretical advances and empirical tests in 20 countries. In M. P. Zanna (Ed.), Advances in Experimental Social Pychology (Vol. 25, pp. 1-65). Nueva York: Academic Press.

Schwartz, S. H. (1999). Cultural value differences: some implications for work. Applied Psychology: An International Review, 48, 23-48. 
Schwartz, S. H. (2006). Les valeurs de base de la personne : théorie, mesures et applications. [Basic Human Values: Theory, methods and applications]. Revue Francaise De Sociologie, 47(4), 929-968.

Schwartz, S. H. (2007). Value orientations. measurement, antecedents and consequences across nations. In R. Jowell, C. Roberts, R. Fitzgerald \& G. Eva (Eds.), Measuring attitudes crossnationally (pp. 169-203). London: Sage.

Schwartz, S. H., Melech, G., Lehmann, A., Burgess, S., \& Harris, M. (2001). Extending the crosscultural validity of the theory of basic human values with a different method of measurement. Journal of Cross-Cultural Psychology, 32(5), 519-542.

Shane, S. (1993). Cultural Influences on National Rates of Innovation. Journal of Business Venturing, $8(1), 59-73$.

Shane, S., Kolvereid, L., \& Westhead, P. (1991). An Exploratory Examination of the Reasons Leading to New Firm Formation across Country and Gender. Journal of Business Venturing, 6(6), 431-446.

Sternberg, R., \& Wennekers, A. R. M. (2005). Determinants and Effects of New Business Creation Using Global Entrepreneurship Monitor Data. Small Business Economics, 24(3), 193-203.

Sutaria, V., \& Hicks, D. A. (2004). New firm formation: dynamics and determinants. Annals of Regional Science, 38(2), 241-262.

Tang, L., \& Koveos, P. E. (2008). A framework to update Hofstede's cultural value indices: Economic dynamics and institutional stability. Journal of International Business Studies, 39(6), 1045-1063.

Thomas, A. S., \& Mueller, S. L. (2000). A case for comparative entrepreneurship: assessing the relevance of culture. Journal of International Business Studies, 31(2), 287-301.

Tiessen, J. H. (1997). Individualism, collectivism and entrepreneurship: A framework for international comparative research. Journal of Business Venturing, 12(5), 367-384.

van Stel, A., Carree, M., \& Thurik, R. (2005). The Effect of Entrepreneurial Activity on National Economic Growth. Small Business Economics, 24(3), 311-321. doi: 10.1007/s11187-0051996-6

van Stel, A., \& Storey, D. J. (2004). The Link Between Firm Births and Job Creation: Is there a Upas Tree Effect? Regional Studies, 38(8), 893-909.

Van Stel, A., Wennekers, A. R. M., Thurik, A. R., \& Reynolds, P. (2003). Explaining nascent entrepreneurship across countries. SCALES-paper N2003-01. Zoetermeer: EIM Business and Policy Research.

Venkatraman, N. (1989). The concept of fit in strategy research: toward verbal and statistical correspondence. Academy of Management Review, 14(3), 423-444.

Verheul, I., Wennekers, A. R. M., Audretsch, D. B., \& Thurik, A. R. (2002). An eclectic theory of entrepreneurship. In D. B. Audretsch, A. R. Thurik, I. Verheul \& A. R. M. Wennekers (Eds.), Entrepreneurship: Determinants and Policy in a European-US Comparison. Boston/ Dordrecht: Kluwer Academic Publishers.

Wennekers, A. R. M., Noorderhaven, N., Hofstede, G., \& Thurik, A. R. (2001). Cultural and economic determinants of business ownership across countries. In W. Bygrave, E. Autio, C. G. Brush, P. Davidsson, P. Green, P. D. Reynolds \& H. J. Sapienza (Eds.), Frontiers of Entrepreneurship Research 2001 (pp. 179-190). Wellesley, MA: Babson College, Center for Entrepreneurial Studies.

Wennekers, A. R. M., Uhlaner, L. M., \& Thurik, A. R. (2002). Entrepreneurship and its conditions: A macro perspective. International Journal of Entrepreneurship Education, 1(1), 25-64.

Wennekers, A. R. M., van Stel, A., Thurik, A. R., \& Reynolds, P. D. (2005). Nascent Entrepreneurship and the Level of Economic Development. Small Business Economics, 24(3), 293-309.

Wennekers, S., Thurik, R., van Stel, A., \& Noorderhaven, N. (2007). Uncertainty avoidance and the rate of business ownership across 21 OECD countries, 1976-2004. Journal of Evolutionary Economics, 17(2), 133-160. 